\title{
2-Level and 3-Level Inverter Topologies for Micro Grid Connected Scheme Using MPPT Based PV Energy System
}

\author{
D.Madhurisrilatha ${ }^{1}$, Y.Vishnumurthulu ${ }^{2}$ \\ ${ }^{1}$ (M-tech Student, Department of Electrical \& Electronics Engineering, \\ Prasad.V.Potluri Siddhartha Institute of technology, Krishna (Dt); A.P, India.) \\ ${ }_{2}^{2}$ (Assistant Professor, Department of Electrical \& Electronics Engineering, \\ Prasad.V.Potluri Siddhartha Institute of technology, Krishna (Dt); A.P, India.
}

\begin{abstract}
With the using of the renewable energy sources increasingly, application of the distributed generation $(D G)$ in the distribution system acquired more attention. The DG systems are powered by micro sources such as fuel cells, photovoltaic (PV) systems, and batteries. Photovoltaic $(P V)$ inverters become more and more widespread within both private and commercial circles. These grid-connected inverters convert the available direct current supplied by the PV panels and feed it into the utility grid. Micro grid concept acts as a solution to integrate large amounts of micro generation without disrupting the operation of utility grid. The uniqueness of the proposed modeling and control includes a complete model's details of micro-grid set up with $P V$ system, power conditioning devices and load model, the utilization of an MPPT and feedback controller to control the output voltage and current and interfaced to grid system using 2-level \& 3-level inverter topology. The dynamic analysis of proposed converter strategies is evaluated with the help of Matlab/Simulink platform and results are conferred.
\end{abstract}

Keywords: Micro Grid Connected System, MPPT Technique, PV Module, Inverter Module, Total Harmonic Distortion.

\section{Introduction}

Renewable energy sources (RESs) have experienced a rapid growth in the last decade due to technological improvements, which have progressively reduced their costs and increased their efficiency at the same time [1]. Moreover, the need to depend less on fossil fuels and to reduce emissions of greenhouse gases, requires an increase of the electricity produced by RESs. This can be accomplished mainly by resorting to wind and photovoltaic generation, which, however, introduces several problems in electric systems management due to the inherent nature of these kinds of RESs [2]. In fact, they are both characterized by poorly predictable energy production profiles, together with highly variable rates. As a consequence, the electric system cannot manage these intermittent power sources beyond certain limits, resulting in RES generation curtailments and, hence, in RES penetration levels lower than expected.

The PV modules are particularly attractive as renewable sources due to their relative small size, noiseless operation, simple installation, and to the possibility of installing them closer to the user. In PV modules, the output voltage has a low dc amplitude value. In order to be connected to the grid, the PV modules output voltage should be boosted and converted into an ac voltage. This task can be performed using one or more conversion stages (multi-stage). Photovoltaic (PV) conversion approach is silent, modular, easily transportable and quickly installed. Power can be generated where it is required without the need of long transmission lines. Actually, terrestrial applications of photovoltaic panels provide auxiliary means of power generation. Also, there are installations in locations where other means of electricity supply would be as costly as photovoltaic panels. Moreover, this kind of installation provides important social benefits to rural communities throughout the world. Unfortunately, once there is a partial shadow on some panels, the system's energy yield becomes significantly reduced [2].

These grid-connected inverters convert the available direct current supplied by the PV panels and feed it into the utility grid. Transformerless PV inverters use different solutions to minimize the leakage ground current and improve the efficiency of the whole system, an issue that has previously been treated in many papers [1]-[3]. One of them is to connect the midpoint of the dc-link capacitors to the neutral of the grid, like the halfbridge, neutral point clamped (NPC), or three-phase full bridge with a split capacitor topology, thereby continuously clamping the PV array to the neutral connector of the utility grid. Half-bridge and NPC type of converters have very high efficiency, above 97\%, as shown in [6]. Furthermore, the topology proposed in [6] reduces the dc current injection, which is an important issue in the case of transformerless topologies and is limited by different standards.

This paper gives information about 2 converters structures, analyzing them regarding quality nature of output voltage, harmonic profile, THD values as per IEC standards. It starts with simpler converters and ends 
with more comprehensive ones, but all of them have the main features: high efficiency, relative low number of semiconductors and the capability to inject energy into the grid without using transformers. Several works have focused on developing PV model and the charge controller. Some of the research efforts also designed power conditioning devices and their controller. This work focuses on the development of a micro-grid model that consists of PV arrays, power conditioning devices and an inverter with overall and individual controller. The model configuration can be tested off-grid or on-grid. This paper proposes the grid tied 2-level \& 3-level inverters are used with PV generation scheme and interfaced to grid system with good voltage profile, the dynamic analysis is performed by using Matlab/Simulink platform and results re conferred.

\section{System Configuration And Mathematical Formulation}

The main objective of this paper is to model, analyze, and conduct case studies on a PV based microgrid. The basic configuration of the system is shown in Fig.1. The following subsections describe each block in the figure.

\section{PV Generator}

A PV generator consists of a PV array comprising of PV modules. Modeling details of PV modules and PV arrays are discussed next.

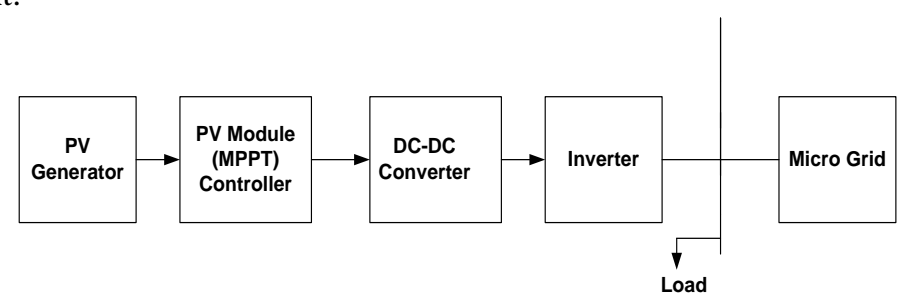

Fig.1 Block Diagram of a PV Micro-grid

\section{PV Cell Model}

A solar module is defined as the individual piece of equipment that encompasses numerous solar cells that are connected in parallel or in series. By putting solar cells together as a module, the current and voltage properties of a module increase. A solar cell can be designed as a p-n junction device where no voltage directly applied across the junction. It converts photon power into electrical power and delivers this power to a load [4]. The p-n junction is fabricated in a thin wafer of semiconductor, usually silicon. In the dark, the p-n has the characteristics of a diode and blocks the flow of the current which results in no voltage. A solar cell equivalent circuit model is shown in Fig.2. This model is called a single-diode model. An ideal module consists of a single diode connected in parallel with a light generated current source.

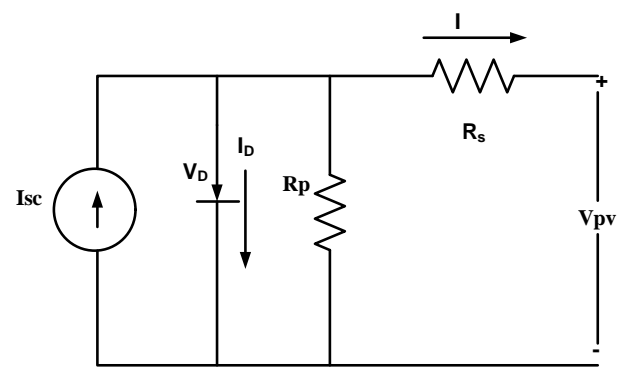

Fig.2. Equivalent Solar Cell Model

In simulation mathematical equations describing the system characteristics are formulated \& translated into computer codes. The value of the source current depends on the light falling on the cell. A stronger light results in a higher electric current. The nonlinear I-V characteristics of the cell are determined by the type of used diode. The photocurrent, Isc, produces a voltage drop across the resistive load which forward biases the $\mathrm{p}-\mathrm{n}$ junction. The forward-bias voltage produces a forward-bias diode current. PV cells are inter-connected to form larger unit called as PV module and these modules are inter connected in parallel/series to form PV arrays.

From fig2.

KCL: Isc- $\mathrm{I}_{\mathrm{D}}-\mathrm{V}_{\mathrm{D}} / \mathrm{Rp}-\mathrm{I}_{\mathrm{PV}}=0$

Diode characteristic: $\mathrm{I}_{\mathrm{D}}=\mathrm{Io}\left(\mathrm{e}^{\mathrm{VD} / \mathrm{Vt}}-1\right)$

KVL: $\mathrm{V}_{\mathrm{pv}}=\mathrm{V}_{\mathrm{D}}-\mathrm{R}_{\mathrm{s}} \mathrm{I}_{\mathrm{PV}}$ 
Pn junction diode current at MPP is given as $\mathrm{Idm}=\mathrm{Isc}-\mathrm{Ir}-\mathrm{Vdm} / \mathrm{Rp}$

Pn junction reverse saturation current is given as $I o=(I s c-V o c c / R p) /(\exp (\operatorname{Vocc} / \mathrm{Vt})-1$

Pn junction diode voltage at MPP is given as $\mathrm{Vdm}=\mathrm{Vt} * \log (\mathrm{Idm} / \mathrm{Io}+1)$ equation I=Isc-ID

ted by the following

Where Isc represents short circuit current of pv module, Ir is current at Pmax of pv module, Vdm is diode voltage at MPP based on incremental resistance, Vocc is cell open circuit voltage, Vt is thermal voltage of cell 26e-3, Rs \& Rp indicate the intrinsic shunt \& series resistances of the cell. Ipv is current of pv cell, Vpv is voltage of pv cell. $\mathrm{I}_{\mathrm{D}}$ is diode current, $\mathrm{V}_{\mathrm{D}}$ is diode Voltage of cell.

Table I Model parameters of PV module

\begin{tabular}{|l|l|}
\hline $\begin{array}{l}\text { Standard Test condition: irradiance of } 1 \mathrm{KW} / \mathrm{m}^{2} \\
\text { temperature of } 25^{0} \mathrm{C} \text {. cell }\end{array}$ \\
\hline Short circuit current (Isc) & 4.9 \\
\hline Short circuit voltage (Voc) & 21 \\
\hline Current at maximum point(Ir) & 4.4 \\
\hline Voltage at maximum point(Vr) & 17 \\
\hline
\end{tabular}

The PV model consists of 8 modules.

\section{MPPT Controller}

Renewable sources, such as solar arrays, produce varying power output. Solar power varies with irradiation (sun power), temperature, and shadowing. To extract the required power from the PV array, it is important to operate at the corresponding maximum power point (MPP). The MPP is unique for each solar module, it is not a fixed point, and it may change based on the required current for a particular load. The Maximum power point tracking (MPPT) is required to match the PV output to load demand. The electrical tracking of the MPP is accomplished through power switching converters. These converters are controlled to provide a matching between the load and the source impedances [2].

For the model presented in this paper, a algorithm is used which works on a simple concept known as perturb and observe $(\mathrm{P} \& \mathrm{O})$ algorithm. The P\&O algorithm is a commonly used MPPT algorithm. It is used for its simplicity and ease of implementation. This method works best for slow changing or constant weather conditions. However, as long as the power increases, the voltage increases or decreases. Once the power decreases, the process is reversed. The algorithm flowchart is shown in fig. 3 where $\mathrm{P}(\mathrm{k})$ is present power. $\mathrm{P}(\mathrm{k}-1)$ is previous power.

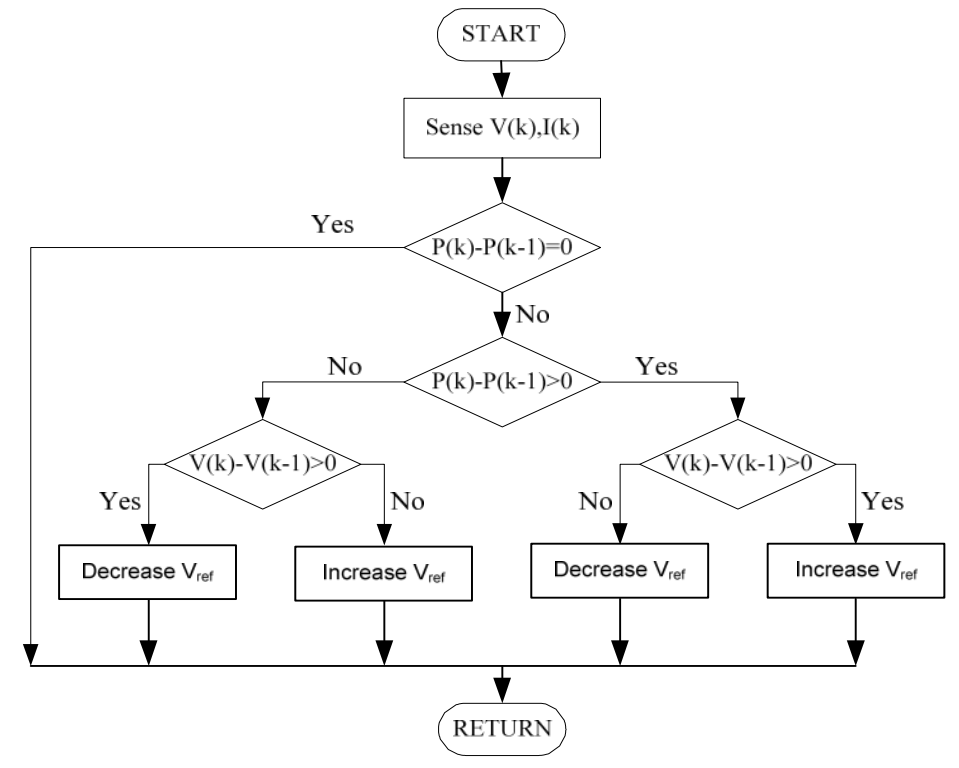

Fig.3 Perturb and Observe Algorithm Flowchart

\section{DC/DC Converter}

A boost converter is a dc to dc voltage converter with an output dc voltage greater than input dc voltage. This is an SMPS containing at least two semiconductors switches, diode which act as freewheeling 
diode two ensure a path of the current during the off state of other switch and a transistor connecting in series of the source voltage). Filters made of capacitor and inductor is used to reduce the ripple in voltage and current respectively, is used at the output stage of the converter. The basic operating principle of the converter consists of the two distinct states. In on state, switch is closed, resulting in an increase in the inductor current. In off state, switch is open, resulting in decrease in the inductor current. In this model Boost converter is used. This is a converter whose output voltage is greater than the input voltage and output current is smaller than the input current.

\section{DC/AC Inverter}

A DC/AC inverter is a device that converts electrical power from DC to AC. In this model single phase inverter is used.

\section{Inverter Modules}

Switch-mode dc-to-ac converters used in ac power supplies and ac motor drives where the objective is to produce a sinusoidal ac output whose magnitude and frequency can both be controlled. Practically, we use an inverter in both single-phase and three phase ac systems. A half-bridge is the simplest topology, which is used to produce a two level \& three level square wave output waveforms. For sinusoidal ac outputs, the magnitude, frequency, and phase should be controllable. According to the type of ac output waveform, these topologies can be considered as voltage source inverters (VSIs), where the independently controlled ac output is a voltage waveform. These structures are the most widely used because they naturally behave as voltage sources as required by many industrial applications, such as adjustable speed drives (ASDs), micro grid connected systems [5], which are the most popular application of inverters.

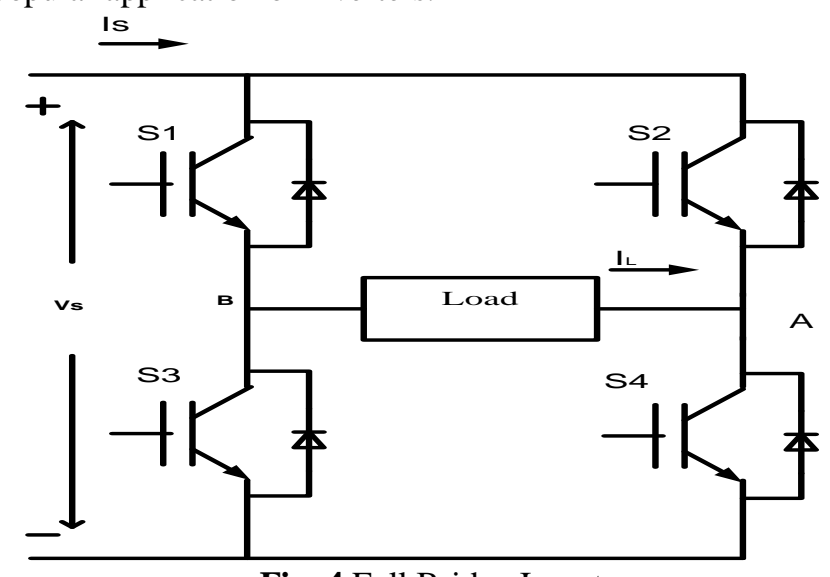

Fig. 4 Full Bridge Inverter

To complete one cycle, $\mathrm{S} 1$ is turned off and S2 is turned on to give a load voltage, VAO, of $-\mathrm{Vs} / 2$. In full bridge configuration, turning on S1 and S4 and turning off S1 and S4 give a voltage of VS between point A and $\mathrm{B}$ (VAB) in Fig. 4, while turning off S1 and S4 and turning on S2 and S3 give a voltage of -Vs. To generate zero level in a full-bridge inverter, the combination can be S1 and S2 on while S3 and S4 off or vice versa. The three possible levels referring to above discussion are shown in Table II.

Table II Switching Pattern of 3 Level Full Bridge Inverter

\begin{tabular}{|l|l|}
\hline Conducing Switches & Load Voltage $\mathrm{V}_{\mathrm{AB}}$ \\
\hline $\mathrm{S}_{1}, \mathrm{~S}_{4}$ & $+\mathrm{Vs}$ \\
\hline $\mathrm{S}_{2}, \mathrm{~S}_{3}$ & $-\mathrm{Vs}$ \\
\hline $\mathrm{S}_{4}, \mathrm{~S}_{3}$ or $\mathrm{S}_{2}, \mathrm{~S}_{1}$ & 0 \\
\hline
\end{tabular}

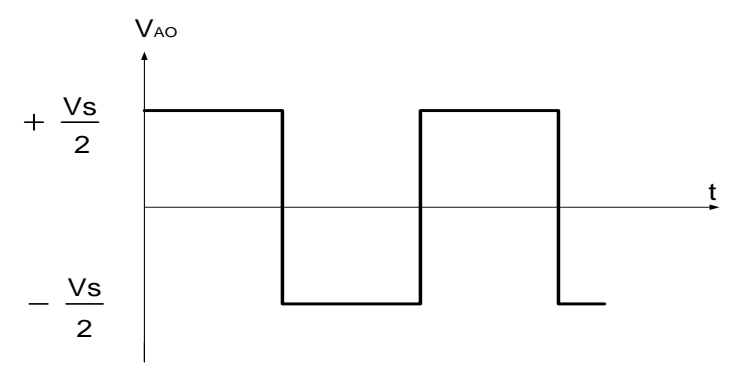

Fig. 5 Output waveform of Half Bridge Inverter 
Note that S1 and S3 should not be closed at the same time, nor should S2 and S4. Otherwise, a short circuit would exist across the dc source. The output waveform of half bridge and full-bridge of single-phase voltage source inverter are shown in Fig. 5 and 6 respectively.

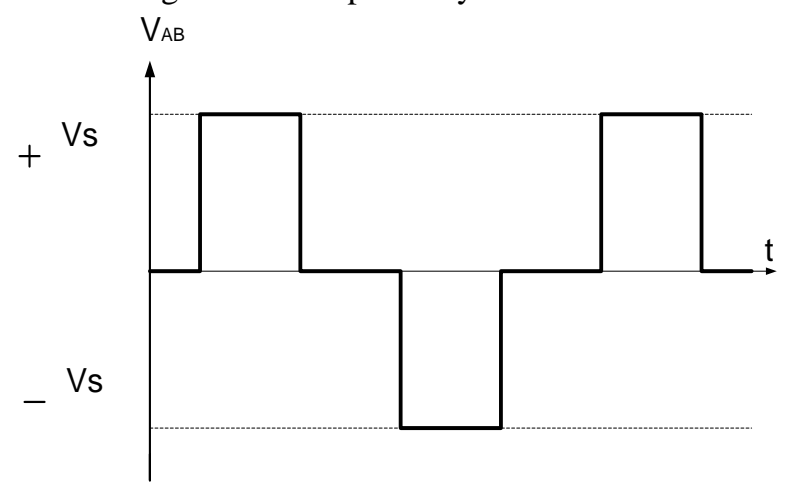

Fig. 6 Output waveform of Full Bridge Inverter

IV. Matlab/Simulink Results

Simulation is carried out for following cases.

Case 1: Proposed PV System Fed to Micro Grid Using 2-Level Inverter Topology

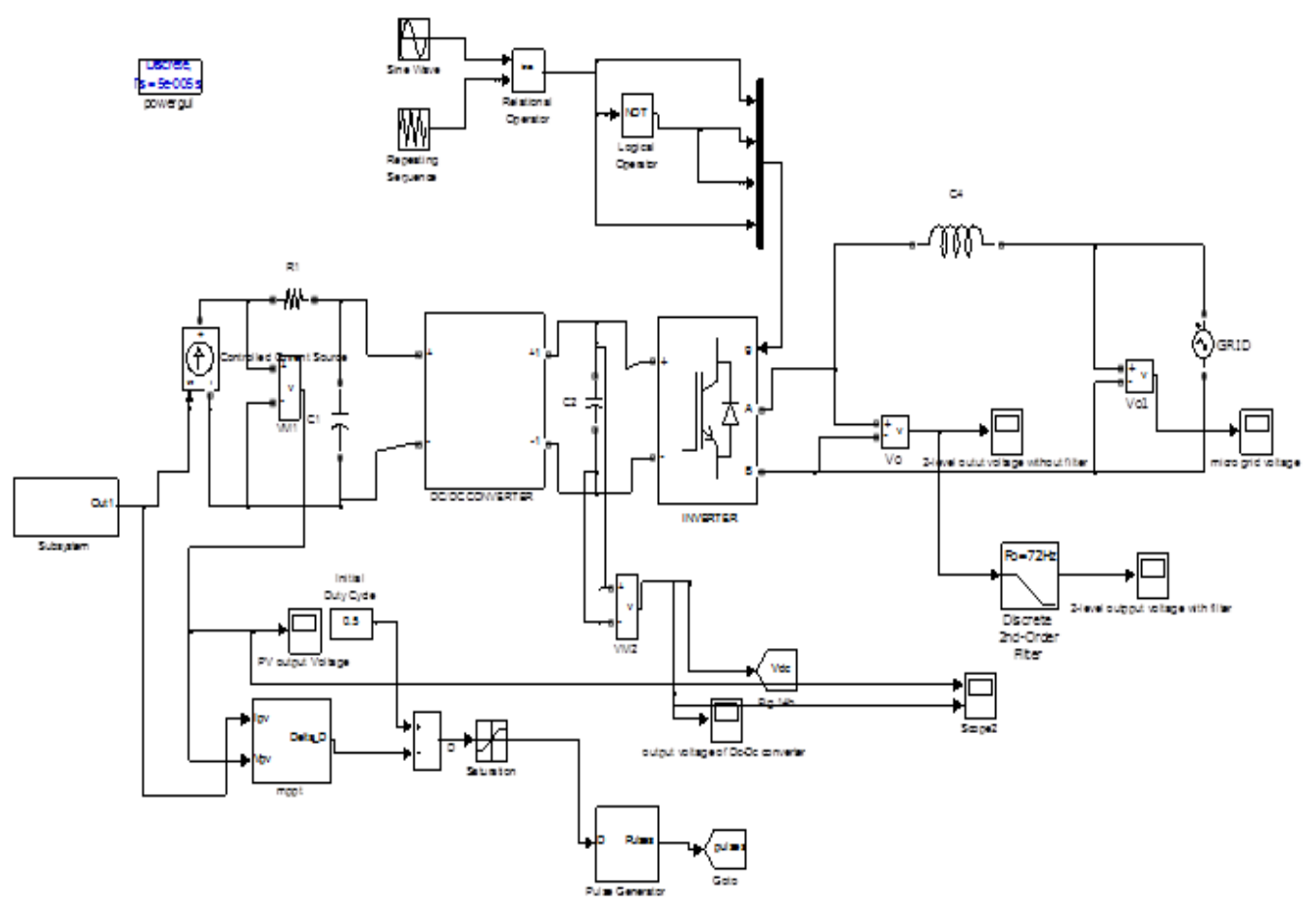

Fig.7 Matlab/Simulink Model of Proposed PV System Fed to Micro Grid Using 2-Level Inverter Topology

Fig.7 shows the Matlab/Simulink Model of Proposed PV System Fed to micro Grid Using 2-Level Inverter Topology using Matlab/Simulink platform. 


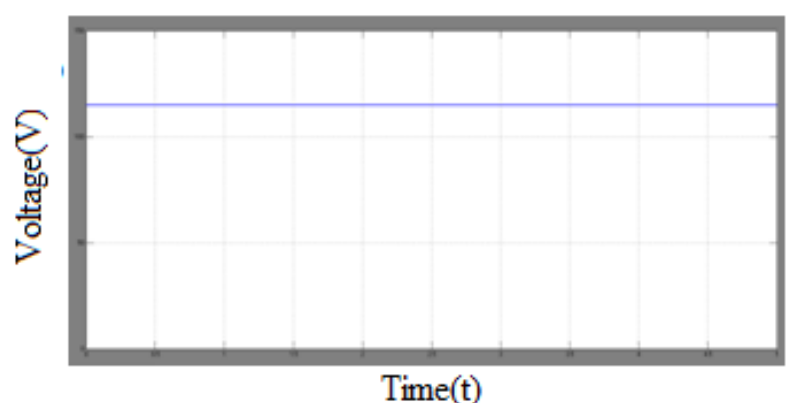

Fig.8 PV Output Voltage

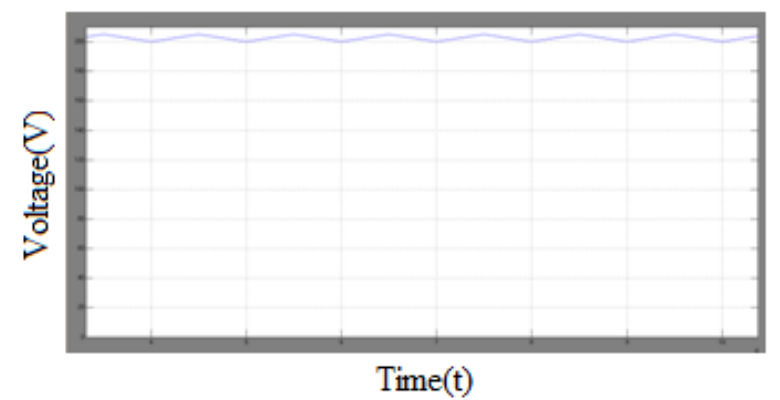

Fig.9 Output Voltage of DC/DC Converter

From fig 8 the obtained PV output voltage is $115 \mathrm{~V}$, and from fig 9 boosted output voltage varies from 200 to $205 \mathrm{~V}$

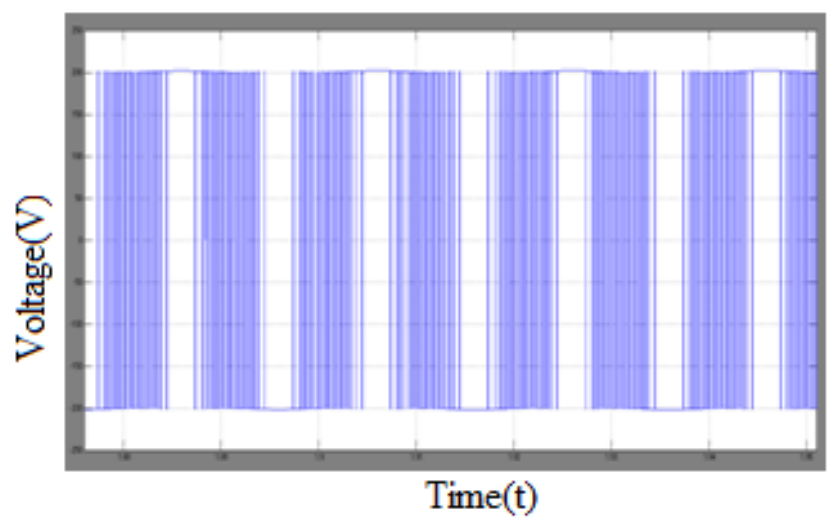

Fig.10 2-Level Output Voltage

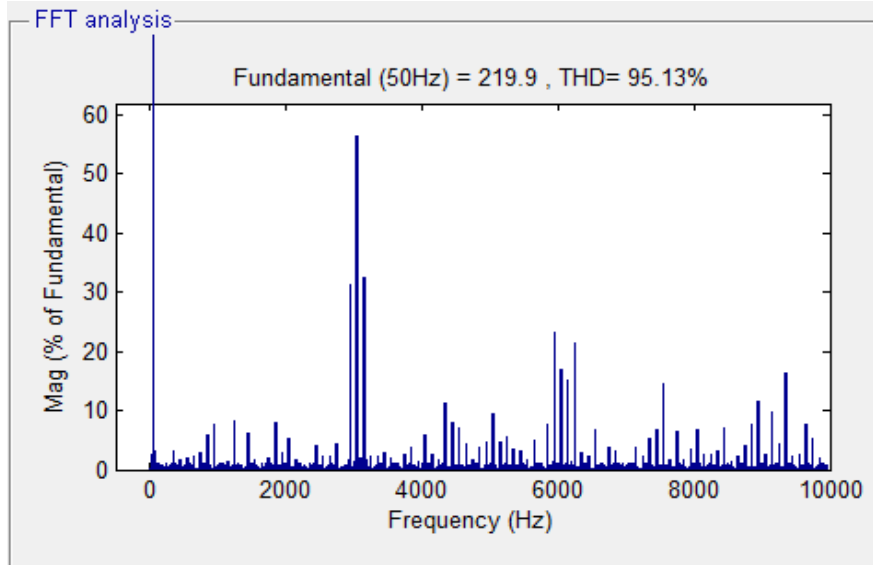

Fig.11 FFT Analysis of 2-Level Output Voltage, attains 95.13\%, while connected to micro grid system without using filter. 


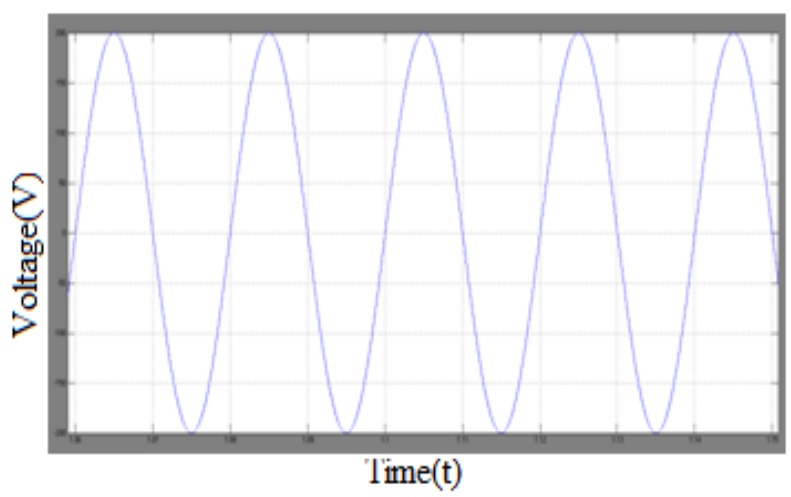

Fig. 12 Micro Grid Voltage

Case 2: Proposed PV System Fed to micro Grid Using 3-Level Inverter Topology

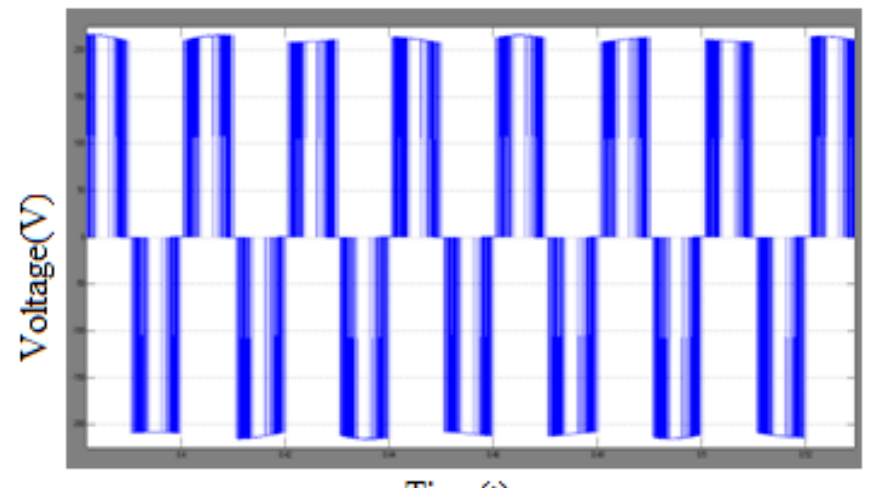

Time(t)

Fig.13 3-Level Output Voltage

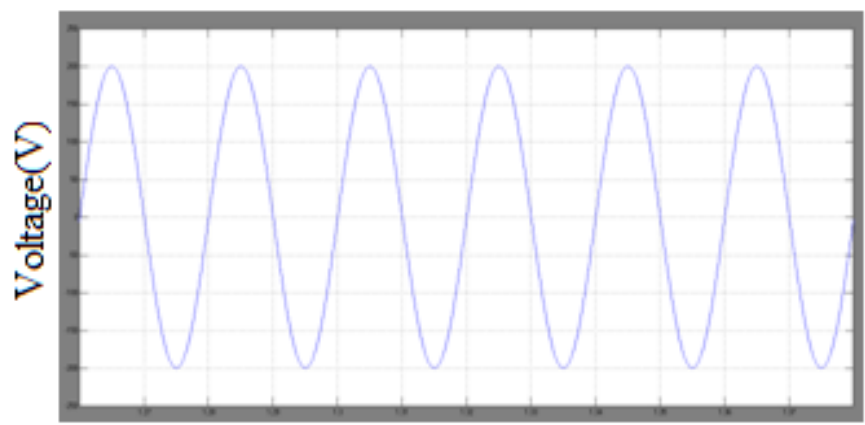

Time(t)

Fig.14 Micro Grid Voltage

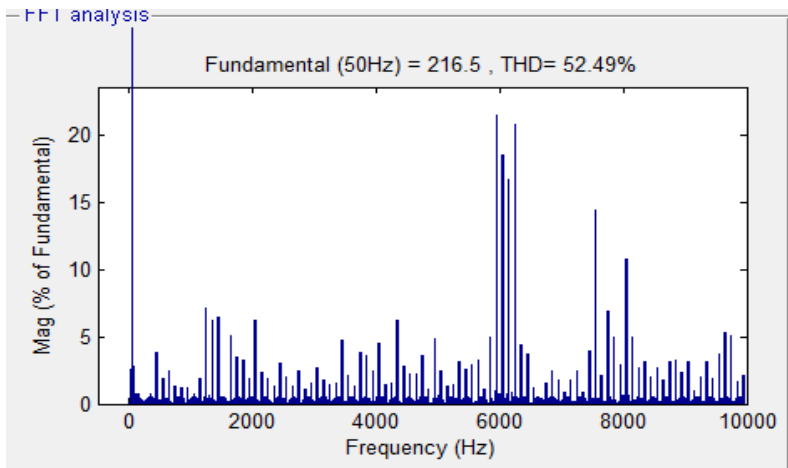

Fig.15 FFT Analysis of 3-Level Output Voltage, attains 52.49\%, while connected to micro grid system without using filter. 
Table III Comparative Analysis of THD Response with 2-Level \& 3-Level Inverter Topologies.

\begin{tabular}{|l|l|l|}
\hline THD (\%) of Vo & Without Filter & With Filter \\
\hline $\begin{array}{l}\text { 2-Level Inverter } \\
\text { Topology }\end{array}$ & $95.13 \%$ & $1.85 \%$ \\
\hline $\begin{array}{l}\text { 3-Level Inverter } \\
\text { Topology }\end{array}$ & $52.49 \%$ & $1.79 \%$ \\
\hline
\end{tabular}

As above Table III specifies the Comparative Analysis of THD Response with 2-Level \& 3-Level Inverter Topologies, with the increment of many levels achieves low THD value with \& without Filter, number of levels increases the THD also goes to reduces and no need to use large size filter at load side/grid side.

\section{Conclusions}

To have sustainable growth and social progress, it is necessary to meet the energy need by utilizing the renewable energy resources like wind, biomass, hydro, co-generation, etc. In sustainable energy system, energy conservation and the use of renewable source are the key paradigm. With the increase in load demand, the Renewable Energy Sources (RES) are increasingly connected in the distribution systems which utilizes power electronic Converters/Inverters. This paper has presented an overview of PV systems, the mathematical formulation and the modeling of all components involved. The model consist of mathematical design and development of PV module and arrays, power conditioning DC/DC converter and the inverter set up. Further, a PV charge controller based on Maximum Power Point Tracking (MPPT) has been developed for the control of PV arrays. These designs are then integrated with an inverter controller that controls the voltage at a power system bus. The complete system is used as a micro-grid set up connected to a power grid. Modeling and evaluations of this model is conducted using 2-level \& 3-level inverter modules. 2-level and 3-level inverter topologies are tested using the simulink. The results of these two inverter topologies are compared and shows that Percentage of THD in 3-level inverter is less than 2-level inverter .

\section{References}

[1]. Huan-Liang Tsai, Ci-Siang Tu, and Yi-Jie Su, "Development of Generalized Photovoltaic Model Using MATLAB/SIMULINK," Proceedings of the World Congress on Engineering and Computer Science, San Francisco, CA, October 22-24, 2008.

[2]. Sukumar Kamalasadan, Khalid s. Al-Olimat "Modeling and control of a Micro-Grid setup Using Photo Voltaic Arrays", IEEE Transactions, 2013 .

[3]. F.M. Gonzalez-Longatt, "Model of Photovoltaic Module In Matlab," Latin American Congress of Students of Electrical Engineering, 2005.

[4]. D.A. Neamen, Semiconductor Physics and Devices. New York: Mcgraw-Hill, 2003.

[5]. Minakshi DebBarma, Sumita Deb, Champa Nandi "Maximum photo voltaic power tracking using perturb and observe algorithm in Matlab/Simulink environment", vol.1, pp.71-84, 2010.

[6]. R. Fracz and A. Dmowski, "Monitoring and Control of Distributed Power Generation Systems such as Photovoltaic System," X International PhD Workshop, pp. 313-316, October2008, http://mechatronika.polsl.pl/owd/pdf/313.pdf.

[7]. T. DenHerder, "Design and Simulation of Photovoltaic Super System Using Simulink," California Polytechnic State University, 2006.

[8]. Jan T. Bialasiewicz, "Renewable Energy Systems With Photovoltaic Power Generators: Operation and Modeling", IEEE Transactions on Industrial Electronics, VOL. 55, NO. 7, JULY 2008.

[9]. V.salas, E.Olyas, A. Barrado, A .Lazaro, " Review of The Maximum Power Point Tracking Algorithms for Stand-Alone Photovoltaic Systems", Solar Energy Materials \& Solar Cells, Vol. 90, pp. 1555-1578, 2006.

[10]. T. Kerekes, D. Sera and R. Teodorescu, "Teaching Maximum Power Point Trackers Using a Photovoltaic Array Model with Graphical User Interface,” Institute of Energy Technology.

[11]. Jeyraj Selvaraj, Nasrudin A. Rahim, "Multilevel Inverter For Grid-Connected PV System Employing Digital PI Controller", IEEE Transactions On Industrial Electronics, vol. 56, No. 1, pp. 149-158, 2009.

[12]. Jose Rodríguez,, Jih-Sheng Lai, Fang Zheng Peng, "Multilevel Inverters: A Survey of Topologies, Controls, and Applications", IEEE Transactions on international electronics, vol .49, NO. 4, AUGUST 2002.

[13]. Kapil Jain, Pradyumn Chaturvedi, "Matlab -based Simulation \& Analysis of Three -level SPWM Inverter", International Journal of Soft Computing and Engineering, vol.2, March 2012.

[14]. Rajesh Kr Ahuja, Lalit Aggarwal2, Pankaj Kumar," Simulation of Single Phase Multilevel Inverters with Simple Control Strategy Using MATLAB”, International Journal of Advanced Research in Electrical, Vol. 2, October 2013. 